\title{
MODEL MANAJEMEN FUNDRAISING WAKAF
}

\author{
Miftahul Huda \\ Sekolah Tinggi Agama Islam Negeri (STAIN) Ponorogo \\ Jl. Pramuka No. 156, Ronowijayan, Ponorogo, Jawa Timur \\ E-mail: elhoeda@yahoo.co.id.
}

\begin{abstract}
Waqf Fundraising Management Model. This article examines models of fundraising through conventional sources, waqf asset productivity at The Al-Falah Social Fund Foundation (YDSF) in Surabaya. This study shows that YDSF uses waqf fundraising management through developing a resource fundraising model such as fundraising method from conventional sources either directly or indirectly as well as grant fundraising model such as strengthening empowerment program on the distribution of endowments. Whereas in developing asset fundraising model and, in-kind waqf, YDSF has not yet developed such a model. Hence the YDSF uses merely the direct cluster management.
\end{abstract}

Keywords: șadaqah jāriyah, al-habs, charitable fundraising management, corporate social responsibility

\begin{abstract}
Abstrak: Model Manajemen Fundraising Wakaf. Artikel ini mengkaji model fundraising wakaf melalui sumber-sumber konvensional, produktivitas aset wakaf, dan in-kind wakaf pada Yayasan Dana Sosial Al-Falah (YDSF) Surabaya. Studi ini menunjukkan bahwa Yayasan ini menggunakan manajemen fundraising wakaf dengan mengembangkan model resource fundraising seperti metode penggalangan dari sumber-sumber konvensional baik secara langsung maupun tidak langsung dan model grant fundraising seperti penguatan program pemberdayaan pada penyaluran wakaf. Sedangkan dalam pengembangan model asset fundraising, dan in-kind wakaf, YDSF belum dapat mengembangkannya sehingga YDSF termasuk nädhir wakaf yang masih dalam kluster pengelolaan wakaf langsung.
\end{abstract}

Kata Kunci: șadaqah jāriyah, al-ḥabs, manajemen fundraising wakaf, corporate social responsibility

\section{Pendahuluan}

Gagasan didirikannya Yayasan Dana Sosial al-Falah (YDSF) Surabaya, bermula dari keinginan beberapa pengurus Yayasan Masjid al-Falah Surabaya, untuk meneruskan kebiasaan yang dilakukan oleh Ketua Yayasan Masjid al-Falah pertama. Hampir setiap hari setelah melaksanakan salat Subuh, dia berkeliling di daerah pinggiran kota Surabaya untuk melihat keadaan masjid atau musala yang sedang dibangun. Apabila bangunan tersebut belum selesai bahkan terbengkalai, ia segera menghubungi beberapa donatur Muslim untuk diajak bersama-sama menyelesaikan pembangunan tersebut. ${ }^{1}$

Dari kebiasaan itu, muncul ide untuk membentuk lembaga yang dikelola dengan baik dan berfungsi sebagai lembaga sosial. Yayasan Dana Sosial al-Falah (YDSF) didirikan 1 Maret 1987. Pada awalnya adalah sebagai lembaga penggalangan dan pendayagunaan dana yang amanah dan profesional sebagai lembaga pengelola infak

Naskah diterima: 23 Oktober 2011, direvisi: 16 Juli 2012, disetujui untuk terbit: 2 Agustus 2012.

${ }^{1}$ Agus Yanto dkk., Sepuluh Tahun YDSF, (Surabaya: Dunia Ilmu, 1997), h. 20. dan sedekah saja. Dalam perkembangan berikutnya, YDSF dikukuhkan menjadi lembaga amil zakat (LAZ) nasional oleh Menteri Agama Republik Indonesia dengan SK No. 523 tanggal 10 Desember 2001 menjadi entitas yang menaruh perhatian pada pelayanan sosial, sehingga aktivitas YDSF lebih meluas dan berkembang. YDSF selanjutnya merespons masyarakat menjadi nädhir wakaf dengan menerima dan menyalurkan harta wakaf yang diamanatkan kepada YDSF, mulai 2006 sampai saat ini. ${ }^{2}$

Penggalangan donatur termasuk wäqif sampai akhir 2009, YDSF telah menghimpun lebih dari 93.000 donatur (khusus YDSF Surabaya) dengan pelbagai potensi, kompetensi, fasilitas, dan otoritas dari kalangan birokrasi, profesional, swasta, dan masyarakat umum telah terajut bersama YDSF membentuk komunitas peduli mustahiq. ${ }^{3}$ Capaian ini tidaklah mudah, dibutuhkan manajemen yang profesional khususnya manajemen penggalangan dana/daya dan manajemen pendayagunaannya untuk mengembangkan lembaga

\footnotetext{
${ }^{2}$ Hasil dokumentasi.

${ }^{3}$ M. Maksum, Hasil Wawancara, 16 Juli 2010.
} 


\section{YDSF ini.}

Dalam mengelola penggalangan sumber daya, penggunaan metode fundraising adalah sangat bervariasi dan seringkali berubah searah dengan berkembangnya YDSF dan peluang yang mudah untuk dikerjakan baik itu melalui individu maupun kelompok. Media yang biasa digunakan adalah majalah, brosur, leaflet, surat kabar, media elektronik, special event, dan sebagainya. Ada juga dengan open table (gerai) pengumpul infak, sedekah, zakat, dan wakaf, seperti acara penerimaan wali murid, membuat konter kecil, adanya pengajian dan acara Ramadan. Sedangkan dari sumber perorangan bisa dikategorikan donatur rumah, lembaga atau organisasi perkantoran dan karyawan perusahaan. Sedangkan dilihat areanya bisa dari dalam negeri ataupun luar negeri, khusus luar negeri adalah para tenaga kerja Indonesia yang bekerja di Hongkong, Korea, dan sebagainya. Penghimpunan sumber-sumber dana/daya termasuk wakaf oleh YDSF sangatlah berkembang ini terbukti penerimaan sumber tersebut mencapai 30 milyar lebih untuk tahun $2009 .{ }^{4}$

Dalam lima tahun terakhir YDSF menerima berupa harta tidak bergerak, seperti tanah di daerah Sidoarjo dan Gresik. Sedangkan wakaf tunai seperti di daerah Lumajang untuk pembangunan tempat ibadah atau masjid dan wakaf tunai juga untuk tujuan pembangunan sekolah di Padang. Dalam tiga-empat tahun terakhir dikembangkan wakaf langsung berupa wakaf tunai, yaitu berupa program wakaf Alquran, Alquran Braille, dan wakaf mobil ambulan. Akan tetapi modelnya tidak seperti sertifikat wakaf uang tetapi masih berupa kuitasi dan bukti apabila wäqif sudah menyetorkan wakaf tunai. $^{5}$

Berkaitan dengan ketersediaan sumber daya wakaf pada nädhir YDSF itu, maka aktivitas fundraising (menggalang sumber daya) wakaf menjadi suatu keniscayaan. Fundraising dapat diartikan sebagai kegiatan dalam rangka menghimpun dana dan sumber daya lainnya seperti wäqifldonatur dari masyarakat ${ }^{6}$ baik individu, kelompok, organisasi, perusahaan ataupun pemerintah yang digunakan untuk mencapai misi atau tujuan lembaga wakaf ${ }^{7}$ dan juga bisa dimaknai sebagai menggalang wäqif untuk mengembangkan usaha-usaha sosial (social enterprise). ${ }^{8}$ Fundraising juga berarti menjual ide, program, dan gagasan yang

${ }^{4}$ Lihat Laporan Tahunan YDSF 2009.

${ }^{5}$ M. Maksum, Hasil Wawancara, 16 Juli 2010.

${ }^{6}$ Kim Klein, Fundraising for Social Change, Fourth Edition (Oakland California: Chardon Press, 2001), h.13.

7 Ahmad Juwaini, Panduan Direct Mail untuk Fundraising, (Jakarta: Piramedia, 2005), h. 4.

${ }^{8}$ Suparman., "Strategi Fundraising Wakaf Uang", dalam Jurnal Wakaf dan Ekonomi Islam, Vol. II, No. 2, April 2009, 13-30. memberikan kemanfaatan kepada masyarakat penerima hasil wakaf. Akhirnya fundraising dapat menumbuhkan kepercayaan dan hubungan dengan masyarakat. Apabila sebuah nädhir sudah mendapatkan citra positif dari masyarakat, maka keberlanjutan program nädhir terus dapat bermanfaat. ${ }^{9}$ Karena itu, sangatlah tepat mengkaji YDSF sebagai $n \bar{a} d h i r$ wakaf relasinya dalam menggalang sumber daya (fundraising) wakaf. Hal ini didasarkan beberapa pertimbangan, yaitu: YDSF sebagai lembaga kedermawaan sosial Islam (infak/sedekah, zakat, dan wakaf) bermisi untuk pelayanan sosial yang paling tua dibanding dengan lembaga yang sama, fundraising sebagai aktivitas utamanya, hasil sumber dana dan skala organisasi yang cukup besar.

Dari paparan di atas, maka artikel ini berupaya menjawab permasalahan tentang bagaimana metode atau model YDSF Surabaya dalam menggalang sumber dana/daya (fundraising) wakaf melalui sumber-sumber konvensional, produktivitas aset wakaf, dan in-kind wakaf.

\section{Substansi Wakaf: Manfaat yang Berkelanjutan}

Wakaf memiliki akar teologis yang kuat. Alquran, meskipun tidak menyebutkan secara eksplisit istilah wakaf, jelas mengajarkan urgensitas kedermawanan sosial untuk pelbagai tujuan yang baik. ${ }^{10}$ Hadis Nabi dan praktik Sahabat menunjukkan bahwa wakaf sesungguhnya bagian dari inti agama Islam. ${ }^{11}$ Namun dalam perkembangannya, institusi wakaf tidak bisa dilepaskan dari dinamika sosial, ekonomi, dan budaya yang mengiringi perkembangan masyarakat Islam dari masa ke masa.

Wakaf dalam bentuk yang sederhana telah dipraktikkan para Sahabat atas petunjuk Nabi. Salah satu yang menjadi dasar praktik wakaf pada masa awal Islam adalah Hadis riwayat Ibn 'Umar. Hadis ini mengisahkan 'Umar ibn Khațtāb mendapatkan

\footnotetext{
${ }^{9}$ Michael Norton, Menggalang Dana: Pedoman bagi Lembaga Swadaya Masyarakat, (Jakarta: Yayasan Obor). 11-16.

${ }_{10}$ Dalam Alquran, istilah "wakaf" tidak dikenal, tetapi intinya adalah sebagai bagian dari suatu perbuatan berderma (filantropi), seperti konsep khayr, konsep infäq dan birr. Istilah "wakaf" dianggap semakna dengan Sadaqah järiyah, al-Babs, tasbil. Lihat Jaih Mubarok, Wakaf Produktif, (Bandung: Simbiosa Rekatama Media, 2008), h. 8-9.

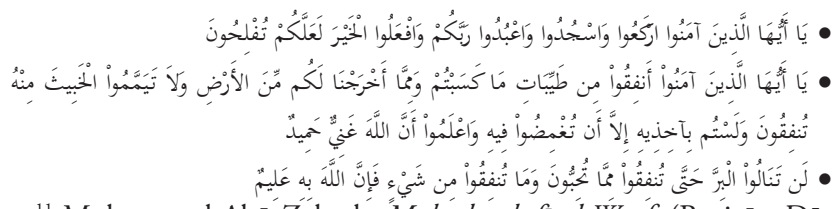

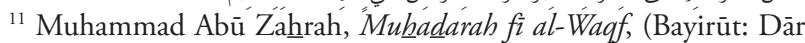
al-Fikr al-'Arbī., t.t.), h. 21); Ahmad Ibārhīm Bik, Mawsü'ah A Ahkām alWaqfi 'alā Madhahib al-Arba'ah, al-Qāhirah: Maktabah al-Azhariyah li al-Turāth|, t.t.), h. 16-18.
} 
sebidang lahan di daerah subur Khaybar dekat Mekah. 'Umar hendak bersedekah dengan lahan ini menanyakan kepada Nabi perihal niatnya tersebut, dan Nabi bersabda, "Jika engkau bersedia tahan asalnya dan sedekahkan hasilnya". ${ }^{12}$

Landasan Hadis ini melahirkan minimal lima prinsip umum yang membentuk kerangka konseptual dan praktik wakaf. Pertama, bahwa kedudukan wakaf sebagai sedekah sunah yang berbeda dengan zakat. Kedua, kelanggengan aset wakaf, sehingga harta wakaf tidak boleh diperjualbelikan, diwariskan maupun disumbangkan. Ketiga, keniscayaan aset wakaf untuk dikelola secara produktif. Keempat, keharusan menyedekahkan hasil wakaf untuk pelbagai tujuan yang baik. Kelima, diperbolehkannya nädhir mendapatkan bagian yang wajar dari hasil wakaf. ${ }^{13}$

Dalam konteks Indonesia dewasa ini sebagai UU No. 41 Tahun 2004 tentang Wakaf, Pasal 1 Ayat (1), wakaf didefinisikan sebagai perbuatan hukum wäqif untuk memisahkan dan/atau menyerahkan sebagian harta benda miliknya untuk dimanfaatkan selamanya atau untuk jangka waktu tertentu sesuai dengan kepentingannya guna keperluan ibadah dan/atau kesejahteraan umum menurut syariah.

Hakikat wakaf dan definisi undang-undang yang lebih longgar di atas menunjukkan bahwa wakaf harus menghasilkan dan memberikan manfaat terusmenerus maka dibutuhkan fungsi-fungsi pengelolaan dan organisasi yang mandiri dan berkelanjutan. Karena itu, wakaf harus dikelola dengan manajemen yang baik dan manajemen fundraising dalam instititusi wakaf merupakan kebutuhan awal yang tidak bisa ditawar lagi.

\section{Praktik Manajemen Nãdhir Wakaf YDSF}

Total Quality Management (TQM), atau di Indonesia lebih dikenal dengan istilah MMT (Manajemen Mutu Terpadu) adalah suatu konsep manajemen yang dikembangkan sebagai usaha peningkatan produktivitas

${ }^{12}$ Diriwayatkan dengan pelbagai redaksi yang hampir sama oleh al-Bukhārī, 1987: II, h. 840; Muslim, III, h. 1255-56; al-Tirmidhī, II, h. 417; Abū Dāwūd, III: h. 116-7; Ibn Mājah, II, h. 801; dan al-Nasāīī, 1420 H, VI, h. 230-2. Lebih lengkapnya lihat al-Bāqī, 2006, h. 31. Adapun redaksinya adalah sebagai berikut:

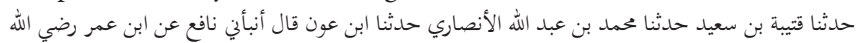

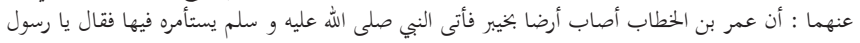

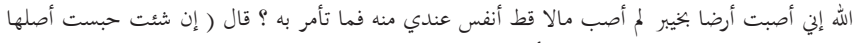

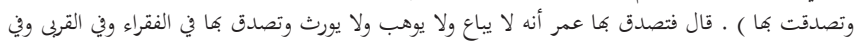

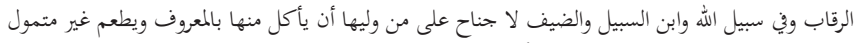

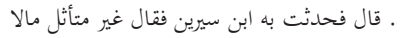

${ }^{13}$ Tuti A. Nadjib dan Ridwal al-Makassary, Wakaf, Tuhan, dan Agenda Kemanusiaan (Jakarta: CSRS UIN Jakarta, 2006), h. 30; Mundzir Qahaf, Al-Waqf al-Islämī Tatawwuruh, Idāratuh, Tanmiyatuh (Dimasyq Syuriah: Dār al-Fikr Qahaf, 2004), h. 52-54. serta peningkatan kualitas barang/jasa harta wakaf. ${ }^{14}$ TQM adalah pendekatan berorientasi pada pelanggan (calon wäqif) yang memperkenalkan perubahan manajemen yang sistematik dan perbaikan terusmenerus terhadap proses, produk dan pelayanan suatu organisasi. Proses TQM bermula dari pelanggan (calon wāqif) dan berakhir pada pelanggan (calon wäqif) pula. Proses TQM memiliki input yang spesifik (keinginan, kebutuhan, dan harapan pelanggan (calon wäqiff), mentranformasi (memproses) input dalam organisasi untuk memproduksi barang atau jasa wakaf yang pada gilirannya, memberikan kepuasan kepada pelanggan (output). ${ }^{15}$

Hakekat TQM, menurut Sashkin dan Kisser sebenarnya adalah filosofi dan budaya kerja organisasi (philosophy of management) yang berorientasi pada kualitas. Tujuan yang akan dicapai dalam organisasi termasuk nädhir wakaf adalah memenuhi atau bahkan melebihi apa yang dibutuhkan (needs) dan yang diharapkan atau diinginkan oleh pelanggan (wäqif dan mawqū f'alayh). ${ }^{16}$

Prinsipnya, TQM adalah suatu pendekatan dalam menjalankanusahayangmencobauntukmemaksimalkan daya saing organisasi lembaga pengelola wakaf melalui perbaikan terus-menerus atau produk jasa, manusia, proses, dan lingkungannya. ${ }^{17}$

Dalam konteks fundraisingwakaf, misalnya, salah satu komponen TQM yang bersinggungan langsung adalah fokus pada kepuasan calon wäqif dan selalu menjaga pengelolaan kualitas proses. Fungsi yang bersinggungan langsung dengan calon wäqif biasa dikenal dengan aspek pemasaran (marketing) berkenaan dengan sisi permintaan-relasi dengan para wāqif (demand side), sedangkan fungsi produksi/operasi berurusan dengan penciptaan program-program fundraising wakaf yang menghasilkan (supply side). ${ }^{18}$

Pemasaran adalah fungsi organisasi dan serangkaian proses menciptakan, mengkomunikasikan dan menyampaikan nilai bagi masyarakat serta mengelola relasi masyarakat sedemikian rupa sehingga memberikan manfaat bagi organisasi dan para stakeholder-nya. ${ }^{19}$ Untuk menggalang dana atau sumber daya wakaf, perlu

${ }^{14}$ Kuat Ismanto, Manajemen Syariah Implementasi TQM dalam Lembaga Keuangan Syariah, (Yogyakarta: Pustaka Pelajar, 2009), h. 58.

${ }^{15}$ Kuat Ismanto, Manajemen Syariah Implementasi TQM, h. 58.

${ }^{16}$ Kuat Ismanto, Manajemen Syariah Implementasi TQM, h. 68.

${ }^{17}$ Fandi Tjiptono dan Anastasia Diana, Total Quality Management, (Yogyakarta: ANDI, 2003), h. 4.

${ }^{18}$ T. Hani Handoko, Dasar-dasar Manajemen Produksi dan Operasi, (Yogyakarta: BPFE-Yogyakarta, 1994), h. 1.

${ }^{19}$ Fandi Tjiptono \& Anastasia Diana, Total Quality Management, h. 5 . 
kemampuan pemasaran dan pengetahuan mengenai prinsip-prinsip pemasaran. Manajemen pemasaran sering diungkapkan oleh Norton ${ }^{20}$ dan Kotler ${ }^{21}$, yang terkenal dengan marketing mix sebagai 5-P, yaitu: planning (perencanaan), product (produk), price (harga), place (tempat), dan promotion (promosi).

Sedangkan manajemen produksi/operasi, Handoko ${ }^{22}$ mendefinisikannya sebagai serangkaian komponen yang fungsinya adalah mengubah seperangkat masukan menjadi pengeluaran yang diinginkan. Masukan menyediakan sumber daya yang dibutuhkan untuk menghasilkan keluaran. Keluaran mencakup barang dan jasa yang diinginkan oleh organisasi. Artinya proses pengubahan/transformasi input menjadi output untuk menambah nilai atau manfaat lebih. Proses produksi berarti proses kegiatan yang berupa: pengubahan fisik, memindahkan, meminjamkan dan menyimpan. Manajemen produksi/operasi merupakan usaha-usaha pengelolaan secara optimal penggunaan sumber daya-sumber daya (faktor produksi: nädhir, modal, teknologi, peralatan, dan lainnya) dalam proses transformasi dari input menjadi produk wakaf seperti program wakaf. Jika dihubungkan antara konsep produksi/operatif pengelolaan wakaf secara umum dan khususnya fundraising wakaf yang dilakukan oleh para nädhir, adalah transformasi dari pengelolaan fundraising wakaf yang alami menjadi lebih profesional untuk menciptakan dan meningkatkan penghasilan atau menambah manfaat. ${ }^{23}$

Dalam konteks menajeman mutu terpadu di atas, YDSF Surabaya terus-menerus mengembangkan pola manajemen sebagaimana dalam konteks manajemen mutu di atas. Hal ini terlihat dalam visi dan misi, paradigma organisasi, sistem manajemen, dan paradigma program YDSF berikut ini.

Sebagai lembaga philantropi Islam, YDSF mempunyai visi menjadi organisasi pengelola zakat, infak, sedekah, dan wakaf nasional terpercaya yang selalu mengutamakan kepuasan donatur (calon wäqif) dan mustahiq (mawqüf 'alayh). Adapun misinya adalah: pertama, memberikan pelayanan prima kepada donatur melalui program-program layanan donatur yang didukung oleh jaringan kerja yang luas, sistem manajemen yang rapi, serta SDM yang amanah dan profesional. Kedua, melakukan kegiatan pendayagunaan

${ }^{20}$ Norton, Menggalang Dana: Pedoman bagi Lembaga Swadaya Masyarakat, h. 468-73.

${ }^{21}$ Lihat Philip Kotler, Manajemen Pemasaran Marketing Managemen Analisis, Perencanaan dan Pengendalian, (Jakarta: Airlangga, 1983).

${ }^{22}$ T. Hani Handoko, Dasar-dasar Manajemen Produksi dan Operasi, h. 3 .

${ }^{23}$ Jaih Mubarok, Wakaf Produktif, h. 15. dana yang terbaik dengan mengutamakan kegiatan pada sektor pendidikan, dakwah, yatim, masjid, dan kemanusiaan untuk menunjang peningkatan kualitas dan kemandirian umat. Ketiga, memberikan keuntungan dan manfaat yang berlipat bagi donatur dan mustahiq. ${ }^{24}$

Sedangkan paradigma organisasi YDSF adalah: pertama, kemampuan YDSF dalam mendayagunakan dana secara amanah dan professional, sehingga menghimpun dana adalah konsekuensinya dan pendayagunaan dana dilaksanakan secara syar'ž, efisien, efektif, dan produktif. Operator pendayagunaan dana YDSF adalah para expert di bidangnya yang mewujud dalam konsorsium pendidikan Islam (KPI), Pusat Dakwah (PUSDA), dan Pusat Layanan Sosial Masyarakat (PLASMA).

Kedua, YDSF adalah lembaga dakwah berbasis sosial yang amanah dan profesional. Seluruh aktivitas YDSF bermuara pada dakwah dengan nilai-nilai universal dan harus memenuhi standard operating procedure manajemen modern. Ketiga, program-program pendayagunaan dana YDSF harus tepat sasaran, tepat guna, dan multiplier effect hingga menimbulkan șadaqah järiyah bagi para donatur.

Keempat, YDSF harus mampu merakit segenap potensi, kompetensi, fasilitas, dan otoritas donatur dan masyarakat baik terkait dengan aktivitas penghimpunan dana maupun aktivitas pendayagunaan dana. Kelima, setiap direktorat YDSF didesain untuk menjadi model yang layak dan mudah ditiru oleh lembaga manapun. Indikator utamanya adalah setiap direktorat menjadi rujukan utama masyarakat dalam beraktivitas di bidang tersebut. Keenam, YDSF harus mampu menembus batas-batas sektarian dan primordialisme dalam menjalankan misi kasih sayang bagi alam semesta. ${ }^{25}$

Adapun sistem manajemen YDSF adalah: pertama, sistem manajemen YDSF dibuat untuk menjamin karyawan agar senantiasa berada pada puncak ketulusan dan profesionalisme (sincerity and professionalism) saat bekerja hingga mampu mencapai the outstanding results tiap menunaikan tugas. Kedua, dalam membangun sistem manajemen direktorat pendayagunaan dana, peran donatur yang ahli (expert) di bidangnya menjadi sentral. Setiap direktorat melakukan benchmarking kepada institusi-institusi donatur dan jejaring YDSF. Ketiga, manajemen YDSF juga melakukan proses promosi, proyeksi dan nominasi SDM di level manajerial dan direksi. Keempat, pengelolaan direktorat

\footnotetext{
${ }^{24} \mathrm{http} / / / \mathrm{www} . \mathrm{yd}$ sf.or.id/program.php?mn=ps\&aksi=list, diunduh 1 September 2010.

${ }^{25} \mathrm{http}: / /$ www.ydsf.or.id/program. php?mn=ps\&aksi=list, diunduh 1 September 2010.
} 
pendayagunaan dana dan penghimpunan dana dibuat dalam boarding terpisah. Sehingga struktur dan SDM terutama level manajer dan direksi dapat berfungsi optimal. ${ }^{26}$

Secara lebih spesifik paradigma program YDSF adalah: pertama, program-program YDSF berorientasi pada masyarakat (market orientation). Karena itu program-program fundraising YDSF berorientasi pada donatur (donors orientation), sedangkan programprogram pendayagunaan dana YDSF berorientasi pada ḍu'afā (poor orientation). Kedua, tiap direktorat harus punya data yang banyak dan akurat tentang bidangnya masing-masing. Ketiga, YDSF terus-menerus memastikan bahwa program-program marketing dan layanan donatur YDSF sesuai dengan keinginan donator. Keempat, YDSF juga selalu memastikan bahwa program-program pendayagunaan dana YDSF bisa menjadi problem solver dari sebagian permasalahan yang sedang dihadapi masyarakat. Kelima, perencanaan dan pelaksanaan program di setiap direktorat YDSF sebisa mungkin berada di dalam koridor shar'ì, amanah, dan profesional. Keenam, Agar dapat efisien, efektif, dan produktif, maka integralitas dan sinergisitas antar program di setiap direktorat YDSF menjadi penting. ${ }^{27}$

Penguatan manajemen mutu yang komprehensif dan integral pada YDSF, akan terlihat juga pada pengembangan model fundraising wakaf.

\section{Model-model Fundraising Wakaf Kontemporer}

Fundraisingtidakidentik hanya dengan menghimpun dana semata. Ruang lingkupnya begitu luas dan mendalam, pengaruhnya sangat berarti bagi eksistensi dan pertumbuhan sebuah lembaga. Oleh karenanya, tidak begitu mudah untuk memahami ruang lingkup fundraising. Untuk memahaminya terlebih dahulu dibutuhkan pemahaman tentang substansi fundraising tersebut. Substansi fundraising dapat diringkas kepada tiga hal, ${ }^{28}$ yaitu: motivasi, program, dan metode. ${ }^{29}$

Adapun yang dimaksud metode atau teknik fundraising, sebagaimana substansi fundraising yang ketiga di atas, adalah suatu bentuk kegiatan yang khas

\footnotetext{
${ }^{26}$ http://www.ydsf.or.id/program.php?mn=ps\&aksi=list, diunduh 1 September 2010.

${ }_{27} \mathrm{http} / / /$ www.ydsf.or.id/program.php?mn=ps\&aksi=list, diunduh 1 September 2010.

${ }^{28}$ Pertama, motivasi. Yakni serangkaian pengetahuan, nilai-nilai, keyakinan dan alasan-alasan yang mendorong calon wäqif untuk mengeluarkan sebagian hartanya. Dalam kerangka fundraising, nädhir harus terus melakukan edukasi, sosialisasi, promosi dan transfer informasi sehingga menciptakan kesadaran dan kebutuhan pada calon wäqif, untuk melakukan kegiatan wakaf atau yang berhubungan dengan pengelolaan wakaf. Kedua, adalah program wakaf, yaitu kegiatan dari

${ }^{29}$ Juwaini, Panduan Direct Mail, h. 5.
}

yang dilakukan oleh nādhir dalam rangka menghimpun dana/daya dari masyarakat. Metode ini pada dasarnya dapat dibagi kepada dua jenis ${ }^{30}$, yaitu langsung (direct) dan tidak langsung (indirect). Adapun tujuan fundraising ada lima hal ${ }^{31}$ yaitu: menghimpun dana/daya wakaf, menambah calon wäqif, meningkatkan citra nādhir, menjalin simpatisan atau pendukung dan memuaskan wäqif. ${ }^{32}$

Seperti diketahui, nādhir dalam mengembangkan manajemen wakaf secara umum harus memperhatikan tiga tahapan penting, ${ }^{33}$ yaitu: tahapan pengumpulan atau

implementasi visi dan misi lembaga perwakafan (nädhir) yang jelas sehingga masyarakat yang mampu tergerak untuk melakukan perbuatan wakaf atau yang terkait dengan perwakafan. Dalam hal ini, nādhir dapat mengembangkan program wakaf dengan siklus fundraising, yaitu membuat kasus program wakaf, melakukan riset segmentasi calon wäqif, menentukan kira-kira teknik yang digunakan untuk menggalang sumber daya wakaf tersebut dan terakhir melakukan pemantuan secara menyeluruh baik proses, efektivitas, maupun hasilnya. Lihat Hendra Sutrisna, Fundraising Database, (Jakarta: Piramedia, 2005), h. 1213. Ketiga, adalah metode fundraising, yaitu pola bentuk atau caracara yang dilakukan oleh sebuah nädhir dalam rangka menggalang dana/daya wakaf dari masyarakat. Metode fundraising harus mampu memberikan kepercayaan, kemudahan, kebanggaan, dan manfaat lebih bagi masyarakat penerima dan wäqif.

30 Pertama, metode fundraising langsung (direct fundraising), yaitu metode yang menggunakan teknik-teknik atau cara-cara yang melibatkan partisipasi wäqif secara langsung. Yaitu bentuk-bentuk fundraising dimana proses interaksi dan daya akomodasi terhadap respons wäqif bisa seketika (langsung) dilakukan. Sebagai contoh dari metode ini adalah: direct mail, direct advertising, telefundraising, dan presentasi langsung. Kedua, fundraising tidak langsung (indirect fundraising), yaitu suatu metode yang menggunakan teknik-teknik atau cara-cara yang tidak melibatkan partisipasi wäqif secara langsung. Yaitu bentuk-bentuk fundraising di mana tidak dilakukan dengan memberikan daya akomodasi langsung terhadap respon wäqif seketika. Metode ini misalnya dilakukan dengan metode promosi yang mengarah kepada pembentukan citra lembaga yang kuat, tanpa diarahkan untuk transaksi daya/dana wakaf pada saat itu. Sebagai contoh dari metode ini adalah: advertorial, image compaign, dan penyelenggaraan event, melalui perantara, menjalin relasi, melalui referensi, dan mediasi para tokoh, dan lainnya (Saidi: 2003).

31 Pertama, menghimpun dana/daya wakaf adalah merupakan tujuan fundraising yang paling mendasar. Kedua, menambah calon wäqif, menambah populasi wäqif. Nädhir yang melakukan fundraising harus terus menambah jumlah donator/wäqif-nya. Ketiga, aktivitas fundraising yang dilakukan oleh nädhir, baik langsung atau tidak langsung akan berpengaruh terhadap citra lembaga. Fundraising adalah garda terdepan yang menyampaikan informasi dan berinteraksi dengan masyarakat. Hasil informasi dan interaksi ini akan membentuk citra lembaga dalam benak masyarakat. Keempat, menjalin simpatisan dan pendukung lembaga meskipun tidak menjadi wäqif. Kelima, dari fundraising adalah memuaskan wäqif. Tujuan ini adalah tujuan yang tertinggi dan bernilai untuk jangka panjang, meskipun dalam pelaksanaannya kegiatannya secara teknis dilakukan sehari-hari. Cara ini sapat dilakukan, misalnya, menyalurkan hasil wakaf sebagaimana amanat wäqif dan secara komunikatif wäqif bisa diajak untuk langsung terjun menyaksikan penyaluran manfaat wakafnya dalam suatu acara yang dirancang nädhir.

${ }_{32}$ Juwaini, Panduan Direct Mail, h. 5-6.

33 Fajar Nursahid, Tanggung Jawab Sosial BUMN, (Jakarta: Piramedia, 2006), h. 27; Wiroso, Penghimpunan Dana dan Distribusi Hasil Usaha Bank Syariah, (Jakarta: Gresindo, 2006), h. 4-5. 
penghimpunan sumber wakaf (resource management), tahapan pengelolaan aset wakaf yang diterima (asset management), dan tahapan pendayagunaan atau pemanfaatan hasil wakaf (grant management). Artinya, pengembangan fundraising dalam tahapan pengelolaan dan pemanfaatan wakaf menjadi perhatian juga.

Mekanisme kerja fundraising wakaf dimaknai bahwa setiap tahapan/pola manajemen wakaf (tahapan daya penghimpunan harta wakaf, daya pengelolaan, daya penyaluran guna/manfaat wakaf) dikombinasikan dengan aktivitas fundraising sehingga dapat memenuhi inti dari fundraising yaitu menghasilkan dan produktif baiksecarafinansial maupun non-finansial. Implikasinya, nädhir harus mengembangkan model fundraising wakaf secara komprehensif dan teramu (ramuan fundraising wakaf) dari mengumpulkan sumber dana wakaf, mengelolanya, dan memanfaatkannya. Aktivitas fundraising wakaf tidak dipisahkan dalam tahapan manajemen wakaf, tidak hanya ketika mengumpulkan atau menghimpun sumber daya wakaf saja tetapi juga ketika mengelola aset wakaf, dan memberdayakan penyaluran manfaat wakaf.

Adapun metode fundraising yang sudah dilakukan YDSF dalam konteks resource fundraising dilihat dari perspektif programnya dapat dipilah menjadi beberapa program, seperti: program rumah cinta yatim, pena bangsa, kemanusiaan, salur tebar hewan kurban, dan program Ramadan. Sedangkan model fundraising secara umum dapat dikelompokkan menjadi: program intensifikasi, program ekstensifikasi, dan program layanan donatur/wāqif. ${ }^{34}$

Sebagai contoh dalam program Ramadan tahun $1430 \mathrm{H}$ nominal dana, baik wakaf maupun non wakaf, yang terhimpun mencapai $\mathrm{Rp} 3.604 .231 .503$,- dengan perincian sebagai berikut: ${ }^{35}$

\begin{tabular}{|l|r|r|r|r|r|}
\hline \multirow{2}{*}{ Keterangan } & \multicolumn{2}{|c|}{$1430 \mathrm{H}$} & \multicolumn{2}{c|}{$1 \mathbf{1 4 2 9} \mathbf{H}$} & \multirow{2}{*}{ Growth } \\
\cline { 2 - 5 } & \multicolumn{1}{|c|}{ perolehan } & \multicolumn{1}{c|}{$\%$} & \multicolumn{1}{c|}{ Perolehan } & \multicolumn{1}{c|}{$\%$} & \\
\hline Zakat & 1.949 .258 .663 & $54,08 \%$ & 1.735 .881 .199 & $40,49 \%$ & $12,29 \%$ \\
Buka Puasa & 244.748 .500 & $6,79 \%$ & 240.633 .500 & $5,61 \%$ & $1,71 \%$ \\
Parcel & 142.170 .000 & $3,94 \%$ & 221.050 .000 & $5,16 \%$ & $-35,68 \%$ \\
Infaq & 499.540 .317 & $13,86 \%$ & 311.689 .217 & $7,27 \%$ & $60,27 \%$ \\
Yatim & 376.028 .000 & $10,43 \%$ & 237.494 .800 & $5,54 \%$ & $58,33 \%$ \\
Wakaf Quran & 68.175 .000 & $1,89 \%$ & 196.452 .500 & $4,58 \%$ & $-65,30 \%$ \\
Wakaf Braile & 50.410 .000 & $1,40 \%$ & 0 & $0,00 \%$ & $\#$ \#IV/0! \\
Cinta guru Qur & 18.175 .000 & $0,50 \%$ & 25.810 .000 & $0,60 \%$ & $-29,58 \%$ \\
Kemanusiaan & 29.537 .400 & $0,82 \%$ & 960.659 .443 & $22,41 \%$ & $-96,93 \%$ \\
Pena Bangsa & 39.808 .500 & $1,10 \%$ & 64.878 .979 & $1,51 \%$ & $-38,64 \%$ \\
lain & 186.380 .123 & $5,17 \%$ & 292.262 .000 & $6,82 \%$ & $-36,23 \%$ \\
\hline Total & $\mathbf{3 . 6 0 4 . 2 3 1 . 5 0 3}$ & $\mathbf{1 0 0 , 0 0 \%}$ & $\mathbf{4 . 2 8 6 . 8 1 1 . 6 3 8}$ & $\mathbf{1 0 0 , 0 0 \%}$ & $\mathbf{- 1 5 , 9 2 \%}$ \\
\hline
\end{tabular}

Program intensifikasi di antaranya terdiri atas: pertama, program intensifikasi donatur/wāqif yang bertujuan untuk mengajak para donatur/wäqif YDSF

\footnotetext{
${ }^{34}$ Lihat laporan Tahunan YDSF 2009.

${ }^{35}$ Laporan Tahunan YDSF 2009.
}

untuk menaikan nilai harta wakafnya. Kedua, program dana peduli koordinator bertujuan untuk meringankan beban para koordinator donatur yang sedang tertimpa musibah, selain itu juga merupakan suatu bentuk apresiasi terhadap para koordinator. Ketiga, program silaturahmi ke koordinator donatur dan donatur premium yang bertujuan untuk meningkatkan tali silaturahmi antara YDSF dan kordinator donatur. ${ }^{36}$

Program ekstensifikasi terdiri atas beberapa program, di antaranya: pertama, program dakwah donatur ke calon donatur yaitu sebuah program baru di divisi penghimpunan. Program ini memotivasi donatur untuk bisa berperan mengajak keluarga, saudara, atau teman untuk menjadi donatur baru di YDSF. Kedua, kegiatan penghimpunan dan sosialisasi program seperti gerai wakaf, gerai zakat, gerai kurban, surat langsung, telepon donatur atau wāqif, penghimpunan lewat elektronik (melakukan proses marketing melalui website, mailing list, dan e-mail), spanduk dan banner, gerakan saudara infak, zakat, dan wakaf di media, dan stiker pencitraan di mobil. Ketiga, gelar stand dengan membuka gerai pada saat event-event tertentu dengan bekerjasama dengan panitia event. Keempat, kerjasama dengan CSR dan pemerintah. Kelima, kerjasama dengan sekolah dan komunitas. ${ }^{37}$

Sedangkan program layanan donatur/wāqif, di antaranya: pertama, acara layanan donatur, seperti: pelatihan menjadi orang tua efektif, keluarga sakinah (excellent family training), membangun tim solid (sinergy building), nanda cerdas peduli (NCP), tarhïb Ramadan, buka bersama koordinator, pelatihan manajemen zakat dan wakaf. Kedua, aktivitas rutin layanan donatur, seperti: layanan pembayaran ziswaf prima, cepat dan tepat, layanan ambulance untuk donatur, layanan SMS cinta (berita dan tausiah), layanan telepon. ${ }^{38}$

Sedangkan dalam mengelola pendayagunaan melalui divisi penyaluran atau pendayagunaan dana dalam program-program yang dilakukan YDSF, adalah: bidang pendidikan dan yatim, bidang dakwah dan masjid, serta bidang kemanusiaan. Ketiga program penyaluran di atas dikonsentrasikan pada lima bidang garap utama yaitu: (1) meningkatkan kualitas pendidikan, (2) merealisasikan dakwah Islamiyah, (3) memakmurkan masjid, (4) memberikan santunan kepada yatim piatu, dan (5) menyalurkan bantuan kemanusiaan. ${ }^{39}$

Dalam pengelolaan penyaluran wakaf seperti wakaf tunai untuk Alquran, Alquran Braille, mobil ambulance, dan untuk bangunan Masjid dan sekolah,

\footnotetext{
${ }^{36}$ Laporan Tahunan YDSF 2009.

${ }^{37}$ Laporan Tahunan YDSF 2009.

${ }^{38}$ Laporan Tahunan YDSF 2009.

${ }^{39}$ Laporan Tahunan YDSF 2009.
} 
prosesnya langsung diserahkan kepada penerima harta wakaf sehingga memberikan manfaat langsung kepada mereka. Sedangkan untuk wakaf tunai mobil ambulance dioperasikan dengan setidaknya memberikan incomel pendapatan bagi YDSF, khususnya bagi anggota donatur yang berjarak jauh dan masyarakat luas. ${ }^{40}$

Praktik menerapkan wakaf seperti ini adalah sudah merupakan kebijakan oleh pengurus dan direspons oleh segenap pengelola/karyawan. Konsep wakaf oleh YDSF dimaknai sebagaimana konsep infak, sedekah, dan zakat. Perbedaannya hanya dalam konteks pemasaran program seperti wakaf tunai dan pembangunan masjid, madrasah, atau sekolah. Karena itu, dapat dipahami dalam pengelolaan wakaf mengikuti pengelolaan infak, sedekah, dan zakat. Ketika penulis berdiskusi dengan pengurus tentang konsep wakaf dan aplikasi pengelolaannya, hemat penulis, YDSF belum mengenal wakaf termasuk aplikasi wakaf uang sesuai dengan semangat UU No. 41 Tahun 2004 tentang Wakaf. Bahkan lahirnya UU Wakaf tersebut juga belum mengetahuinya. Hal ini menunjukkan bahwa pemahaman YDSF tentang institusi wakaf sangat kurang dan bahkan cenderung kurang mengenalnya. ${ }^{41}$

Walapun demikian, YDSF tetap merespons adanya program-program wakaf sesuai dengan pemahaman dan kemampuan pengelolaan lembaga. Hal ini terbukti hasil penggalangan sumber-sumber wakaf relatif menghasilkan. Pada 2009 saja jumlah donasi yang masuk secara keseluruhan termasuk wakaf tunai sebesar Rp 30.097.221.688,-. Sedangkan untuk wakaf tunai sebesar Rp 542.920.500,- dengan tanpa melihat aset dalam bentuk harta tidak bergerak yang belum terkonfirmasi seperti aset tanah wakaf di Gresik dan Sidoarjo. Adapun perincian wakaf tunai yang dihimpun selama 2009 sebagai berikut:

\begin{tabular}{lccc}
\hline \multicolumn{1}{c}{ KETERANGAN } & >2009 & 2009 & JUMLAH \\
\hline Wakaf Alquran & 264.627 .500 & 60.395 .000 & 325.022 .500 \\
\hline $\begin{array}{l}\text { Wakaf Alquran } \\
\text { Braille }\end{array}$ & 50.410 .000 & 60.530 .000 & 110.940 .000 \\
\hline $\begin{array}{l}\text { Wakaf Cinta Guru } \\
\text { Alquran }\end{array}$ & 43.985 .000 & 102.641 .000 & 102.641 .000 \\
\hline $\begin{array}{l}\text { Wakaf Mobil } \\
\text { Ambulance }\end{array}$ & -60.214 .500 & 60.214 .500 \\
\hline $\begin{array}{l}\text { Wakaf Pembangunan } \\
\text { Masjid }\end{array}$ & - & 100.000 .000 & 100.000 .000 \\
\hline $\begin{array}{l}\text { Wakaf Pembangunan } \\
\text { Sekolah }\end{array}$ & -100.000 .000 & 100.000 .000 \\
\hline $\begin{array}{l}\text { Total Penghimpunan } \\
\text { Wakaf Tunai }\end{array}$ & 359.022 .500 & 542.920 .500 & 901.943 .000 \\
\hline
\end{tabular}

${ }^{40}$ Hari S, Hasil Wawancara, 16 Oktober 2010.

${ }^{41}$ Laporan Tahunan YDSF 2009.
Dari konsepsi dan mekanisme kerja fundraising di atas, terlihat bahwa manajemen fundraising wakaf pada YDSF berkembang dengan produktif dan menghasilkan baik secara finansial maupun non-finansial dalam konteks resource fundraising dan grant fundraising. Sedangkan dalam konteks asset fundraising, YDSF belum dapat mengembangkannya karena persoalan latar historis YDSF sebagai lembaga infak dan zakat serta adanya kebijakan dari pengurus dan pembina YDSF untuk tidak mengembangkan atau memproduktifkan aset wakaf yang telah masuk. Penerimaan aset wakaf secepatnya disalurkan kembali secara langsung kepada mustabiq-nya. ${ }^{42}$

Realitas di atas memang cukup mengejutkan. Wakaf produktif biasanya dapat berkembang ketika dalam pengelolaan aset juga produktif, atau dalam kajian ini menggalang sumber daya/dana wakaf melalui penciptaan hasil usaha lewat pengembangan aset wakaf. Dalam kasus YDSF Surabaya, ternyata lebih mengedepankan dan kuat dalam memobilisasi sumber-sumber daya/dana termasuk wakaf dan aspek pendayagunaannya. Artinya, pengelolaan wakaf masih dalam kluster pengelolaan wakaf langsung atau konsumtif. Hal ini diakui oleh YDSF sendiri, alasan utama adalah pemahaman tentang pengelolaan wakaf yang masih minim dan tradisi YDSF sebagai lembaga infak, sedekah, dan zakat masih kuat. Karena itu, saat ini YDSF mulai memprogramkan pengembangan aset wakaf, baik secara kelembagaan maupun manajerial.

\section{Penutup}

Yayasan Dana Sosial al-Falah (YDSF) Surabaya menggunakan manajemen fundraising wakaf dengan mengembangkan model resource fundraising seperti metode penggalangan darisumber-sumber konvensional baik secara langsung maupun tidak langsung dan model grant fundraising dengan metode penguatan program pemberdayaan pada penyaluran wakaf. Sedangkan dalam pengembangan model asset fundraising (produktivitas aset), dan in-kind wakaf, YDSF belum dapat mengembangkannya sehingga YDSF termasuk nädhir wakaf yang masih dalam kluster pengelolaan wakaf langsung atau konsumtif. []

\section{Pustaka Acuan}

'Abd al-Bāqā, Ibrāhīm Mạ̣mūd, Dawr al-Waqfî̀ fì Tanmiyah al-Mujtama' al-Madanì (Namüdaj alAmānah al-'Ammah li al-Awqäf bi Dawlah alKuwayt), Dawlah Kuwayt: Al-Amānah al-Āmmah li al-Awqāf Idārah al-Dirāsah wa al-Alāqāt al-

\footnotetext{
${ }^{42}$ Arief, Hasil Wawancara, 16 Juli 2010.
} 
Khārijiyyah, 2006.

Bik, Ahmad Ibrāhīm, Mawsūah Ahkām al-Waqfi 'alā Madhāhib al-Arba'ah, al-Qāhirah: Maktabah alAzhariyah li al-Turāth, 2009.

Dacanay, Marie Lisa M, Creating Space in The Market, Philipinne: Asian Institute of Management and Conferece of Asian Foundations and Organizations, 2004.

Fuad, Muhammad, Membangunkan Raksasa Tidur, Jakarta: Piramedia, 2008.

Handoko, T. Hani, Dasar-dasar Manajemen Produksi dan Operasi, Yogyakarta: BPFE-Yogyakarta, 1994.

Hasanah, Uswatun, "Potret Filantropi Islam di Indonesia", dalam Thaha, Idris (ed)., Berderma untuk Semua: Wacana dan Praktek Filantropi Islam, Jakarta: PBB UIN Jakarta dan FF.

Hasil Wawancara dan Dokumentasi dilakukan pada bulan Juli-Oktober 2010.

Holloway, Richard, Menuju Kemandirian Keuangan, Jakarta: Yayasan Obor, 2001.

Ismanto, Kuat, Manajemen Syariah Implementasi TQM dalam Lembaga Keuangan Syariah, Yogyakarta: Pustaka Pelajar, 2009.

Iswoyo, Setyo dan Hamid Abidin, In Kind Fundraising, Jakarta: Piramedia, 2006.

Juwaini, Ahmad, Panduan Direct Mail untuk Fundraising, Jakarta: Piramedia, 2005.

Klein, Kim, Fundraising for Social Change, Fourth Edition, Oakland California: Chardon Press, 2001.

Kotler, Philip, Manajemen Pemasaran Marketing Managemen Analisis, Perencanaan dan Pengendalian, Jakarta: Airlangga, 1987.

Miles, Matthew B and A Michel Huberman, Qualitative Data Analysis, Jakarta: Universitas Indonesia Press, 1994.

Mubarok, Jaih, Wakaf Produktif, Bandung: Simbiosa Rekatama Media, 2008.

Nadjib, Tuti A. dan Ridwal Al-Makassary, Wakaf, Tuhan, dan Agenda Kemanusiaan, Jakarta: CSRS UIN Jakarta.

Nasution, Mustafa Edwin dan Uswatun Hasanah (Ed), Wakaf Tunai Inovasi Finansial Islam, Jakarta: PSTTI UI.

Norton, Michael, Menggalang Dana: Pedoman bagi Lembaga Swadaya Masyarakat, Jakarta: Yayasan Obor, 2002.
Nursahid, Fajar, Tanggung Jawab Sosial BUMN, Jakarta: Piramedia, 2006.

Pujihardi, Yuli, Panduan Menggalang Dana Perusahaan, Jakarta: Piramedia, 2006.

Qahaf, Mundzir, Manajemen Wakaf Produktif, Jakarta: Khalifa, 2007. Dalam edisi aslinya berjudul: AlWaqf al-Islāmī Tatawwuruh, Idāratuh, Tanmiyatuh, Dimasyq Syuriah: Dār al-Fikr, 2006.

Saidi, Zaim (Ed.), Kewiraswastaan Sosial Strategi Pengembangan Bisnis Berwawasan Sosial bagi Lembaga Swadaya Masyarakat (LSM), Jakarta: Piramedia, 2005.

Salim, Agus, Teori dan Paradigma Tulisan Sosial, Yogyakarta: Tiara Wacana, 2006.

Stoner, James AF \& Charles Wankel, Manajemen, Jakarta: Intermedia, 1986.

Suparman, "Strategi Fundraising Wakaf Uang", dalam Jurnal Wakaf dan Ekonomi Islam, Vol. II, No. 2, April 2009.

Sutisna, Hendra, Fundraising Database, Jakarta: Piramedia, 2006.

Sya'īb, Khālid 'Abd Allāh, Al-Nazārah 'alā al-Waqfî, Dawlah Kuwayt: Al-Amānah al-Āmmah li al-Awqāf Idārah al-Dirāsah wa al-'Alāqāt alKhārijiyyah, 2006.

Tjiptono, Fandi dan Anastasia Diana, Total Quality Management, Yogyakarta: ANDI, 2003.

Tjiptono, Fandi, Gregorius Chandra, dan Dedi Adriani, Pemasaran Stratejik, Yogyakarta: ANDI, 2008.

Udovitch, Abraham L, Kerjasama Syariah, Kediri: Qubah, 2008.

Undang-undang No. 41 Tahun 2004 tentang Wakaf.

Wiroso, Penghimpunan Dana dan Distribusi Hasil Usaha Bank Syariah, Jakarta: Gresindo, 2006.

www.ydsf.or.id/program.php?mn=ps\&aksi=list, diunduh 1 September 2010.

Yanto, Agus, dkk, Sepuluh Tahun YDSF, Surabaya: Dunia Ilmu, 1997.

Yin, Robert K., Studi Kasus (Desain dan Metode), Jakarta: RajaGrafindo Persada, 2002.

Zahrah, Muhammad Abū, Muhäẹarah fì al-Waqf, Bayrūt: Dār al-Fikr al-'Arabī, 1971.

Zarqā, al-, Musṭafā Aḥmad, Aḥkām al-Awqāf, Dār 'Amār, t.t. 